\title{
Renewable Energy Systems: Technologies and Applications for Future Electric Grid
}

\author{
Saravanan Vasudevan, Arumugam Murugesan \\ Department of Electrical \& Electronics Engineering, Arunai Engineering College, Tiruvannamalai, Tamilnadu, India
}

Email address:

vsaranaec@yahoo.co.in (S. Vasudevan),drmarumugam@yahoo.com (A. Murugesan)

\section{To cite this article:}

Saravanan Vasudevan, Arumugam Murugesan. Renewable Energy Systems: Technologies and Applications for Future Electric Grid. Journal of Electrical and Electronic Engineering. Vol. 5, No. 1, 2017, pp. 1-6. doi: 10.11648/j.jeee.20170501.11

Received: January 19, 2017; Accepted: February 13, 2017; Published: March 3, 2017

\begin{abstract}
Renewable energies can substantially improve the increasing energy demands and mitigate greenhouse gas emissions. It also provides direct and indirect social benefits such as reducing the health and environmental impacts associated with the use of fossil and nuclear fuels, thereby improving standard of living, educational opportunities, creating jobs, reducing poverty, increasing gender equality and ensures energy security. Hybrid renewable energy systems comprising of solar and wind will be effective for efficient power generation, in spite of variability, intermittency and other grid related issues. Prospects and insights of solar photovoltaic and wind energy systems will be discussed by analyzing information reported in various literatures, government and international renewable energy agencies. Also policies and initiatives related to hybrid energy systems concerning environment and economy will be addressed. The progressive path for renewable energy development will be suggested through increased use of renewable energy generation with enhanced reliability, security and resiliency of the future electric grid.
\end{abstract}

Keywords: Renewable Energy, Solar, Wind

\section{Introduction}

Government of India have recently announced a massive renewable power production target of $175 \mathrm{GW}$ by 2022; this comprises generation of $100 \mathrm{GW}$ from solar, $60 \mathrm{GW}$ from wind, $10 \mathrm{GW}$ from biomass, and $5 \mathrm{GW}$ from small hydro power projects. Almost all the state governments in India have released their state renewable energy policy and the stipulated targets. Also electricity regulators have issued regulatory and tariff orders. Such proactive action at the apex level has resulted in a commendable penetration of renewable energy in the overall Indian Energy Mix. Various policy measures supporting capacity addition of renewable energy projects in India are National Action Plan of Climate Change, National Solar Mission, Renewable Purchase Obligations (RPO) and Renewable Energy/Green Certificates. Global investment in renewables rose from USD 55 billion in 2004 to more than USD 260 billion in 2014, with renewable power growing by $85 \%$, to constitute $30 \%$ of installed capacity. In India, already renewable investments are made approximately upto 5.5 billion USD and it is expected to make additional investments of 80 billion USD by 2022. IREDA had released the compendium of state government policies on renewable energy sector in India. It contains a comprehensive summary of all States/Union Territories policies on various renewable sectors, covering the aspects related to land acquisition, power evacuation facilities, frame work for grid connectivity and other financial aspects. A detailed report by IREDA contains the combined summary of CERC \& SERCs Regulations / Tariff Orders of various states for solar PV and solar thermal power projects. It gives the details of Tariff/Control period, Financial/Normative parameters, CDM benefits, subsidy/incentives, taxes \& duties, evacuation facilities, and transmission/wheeling/banking charges. Solar power comes under various programmes such as Roof top PV \& Small Solar Power Generation Programme (RPSSGP) by Indian Renewable Development Agency, various batches and phases of JNNSM, NTPC VidyutVyapar Nigam Limited and Solar Energy Corporation of India (SECI) through schemes like state specific bundling scheme, Viability Gap Funding (VGF) and Generation Based Incentive (GBI) and so on from National Clean Energy Fund. [1] The break-up of renewable power target set by the Government of India for 2022 is given in Fig. 1. 


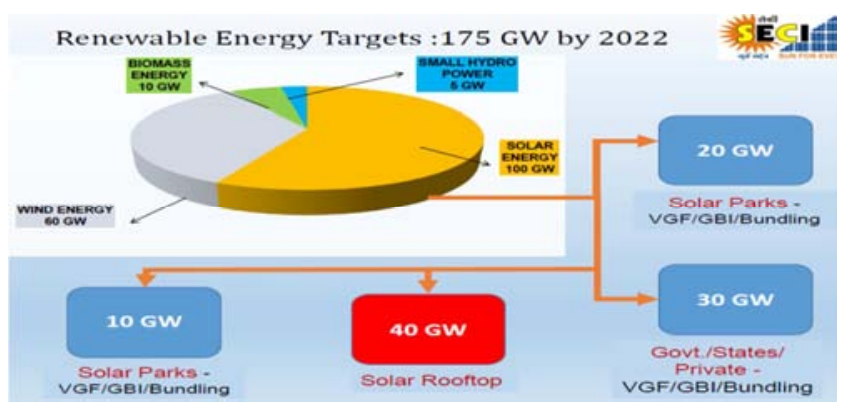

Figure 1. Break-up of the Renewable energy target set by the Government of India for 2022.

\section{Solar and Wind Technologies - Global Perspective}

REN21, a global renewable energy policy agency in its annual renewables global status report $2016[2,3]$ observed a comprehensive and timely overview of renewable energy market, industry, and investment and policy developments worldwide, which enables policymakers, industry, investors and civil society to make informed decisions. New investments are made in the order of 42 USD billion and 67 USD billion by developed and developing countries respectively in the wind sector. More than $785 \mathrm{GW}$ of renewable power generation capacity was added globally by the end of 2015 as shown in Fig. 2.

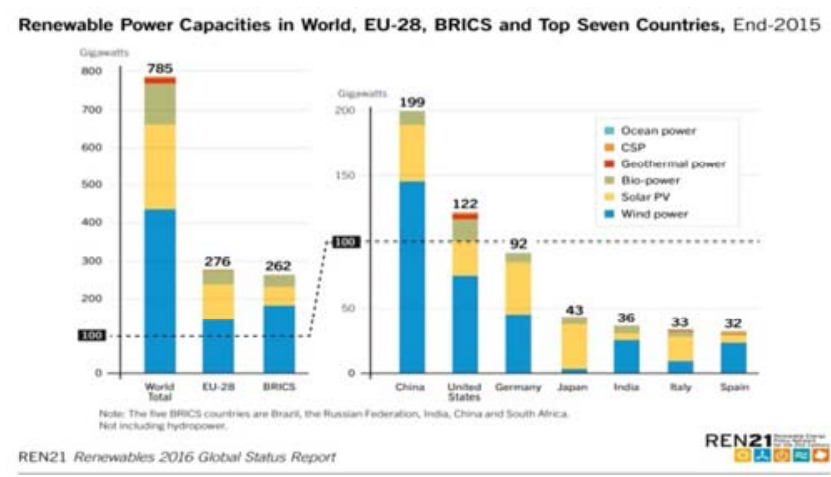

Figure 2. Renewable power capacities of the world by the end of 2015.

Various power policies are practiced throughout the world are feed in tariff, tendering and net metering between 20112015. The global new investment in renewable power and fuels shows that India had invested about 69.8 billion USD for the period from $2004-2015$. It is expected to generate about 1, 25,000 direct and indirect jobs alone in solar PV industry. India had devised its renewable energy policy and targets with the help of feed in tariff mechanism, tendering and net metering schemes. More than $227 \mathrm{GW}$ of solar PV generation capacity was added globally, dominantly supported by feed in tariff (FiT) scheme as shown in Fig 3. Details of top ten countries in the world which have higher solar PV capacity and additions by the year 2015 are given in Fig. 4.

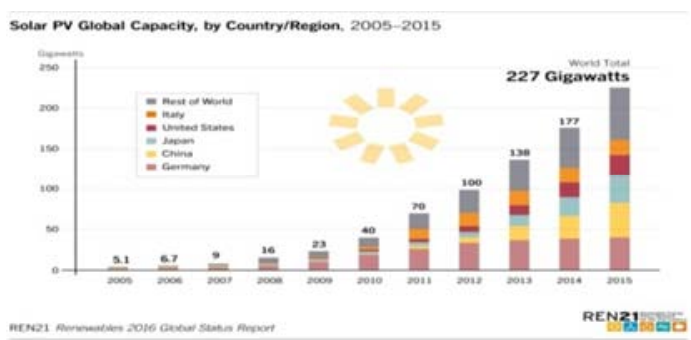

Figure 3. Solar PV global capacity between2005 - 2015.

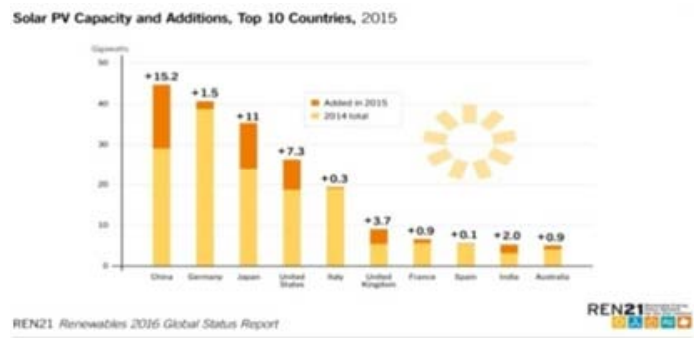

Figure 4. Solar PV capacity and additions, 2015.

Wind power global capacity reached $433 \mathrm{GW}$ globally and India stands $4^{\text {th }}$ place in wind power generation with $27 \mathrm{GW}$ after China, USA and Germany as shown in Figs. 5 and 6

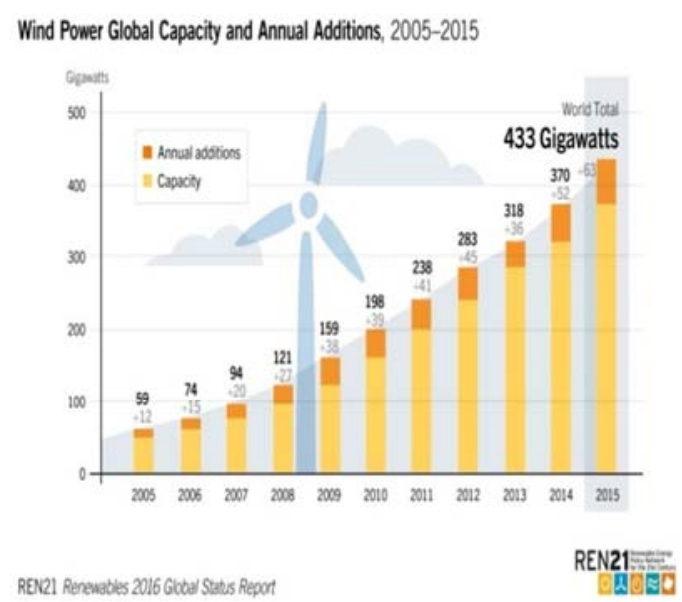

Figure 5. Wind power global capacity by 2015.

Wind Power Capacity and Additions, Top 10 Countries, 2015

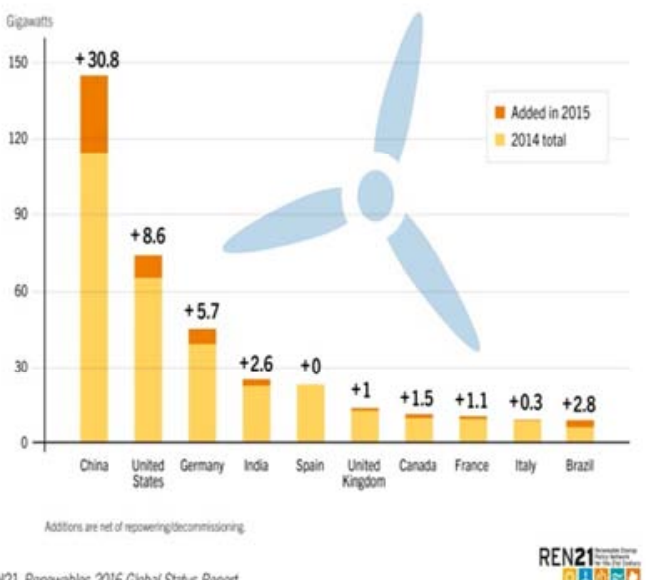

REN21 Renemables 2016 Gibbal Saltis Report

Figure 6. Wind power capacity, top 10 countries by 2015. 


\section{Development in Photovoltaic/Wind Energy System Technologies}

Fig. 7 shows the different solar cells efficiencies by different laboratories in the global market by the end of 2016. [4]

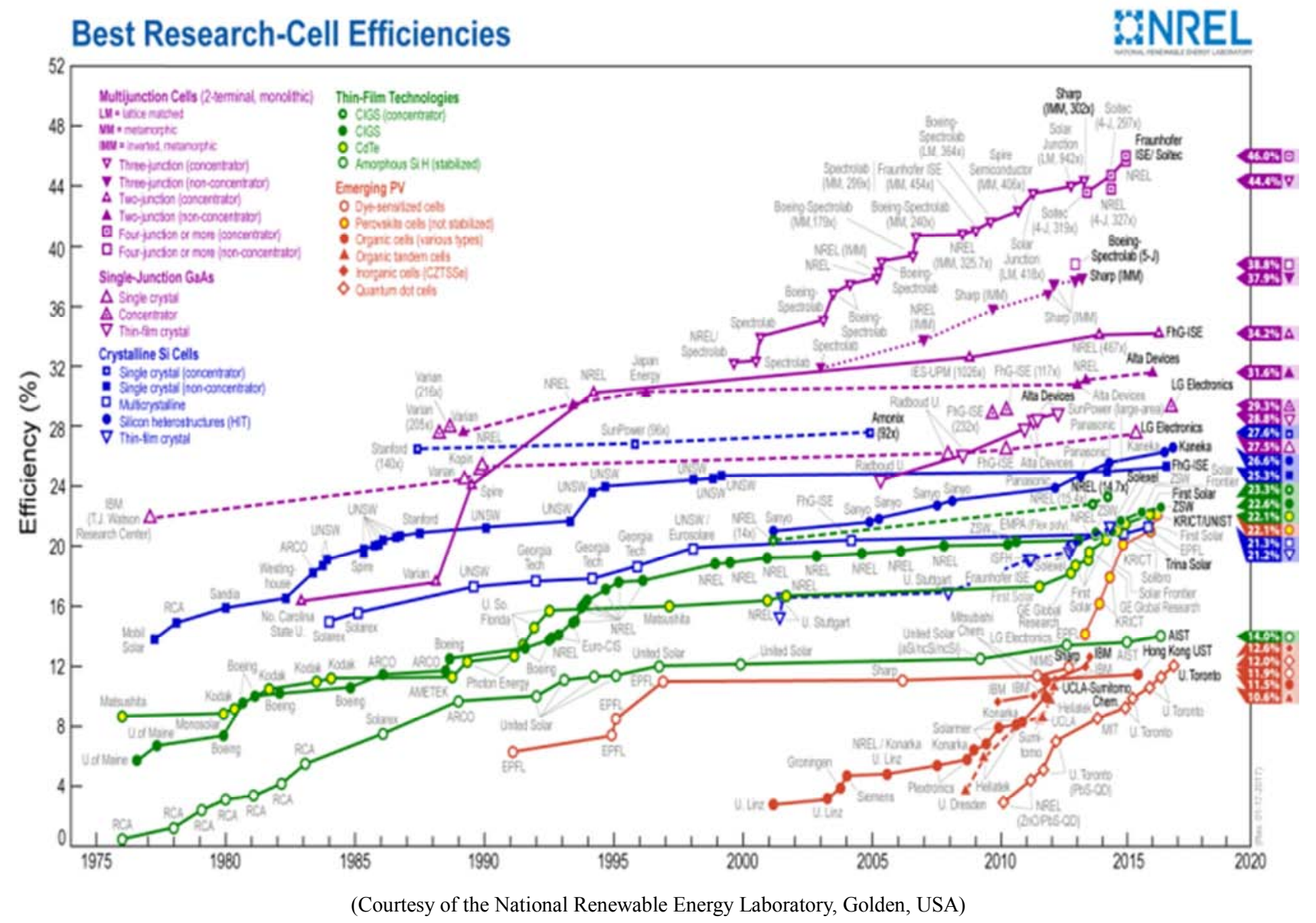

Figure 7. Solar cells efficiencies found by different laboratories in the global market by the end of 2016.

As per the Photovoltaics report of Fraunhofer Institute for Solar Energy Systems, ISE, Freiburg, 17 November 2016 [5], the efficiency comparison of different types of PV modules and inverters used are listed in Tables. 1 and 2 respectively.

Table 1. Efficiency comparison of different types of PV modules.

\begin{tabular}{lllll}
\hline \multirow{2}{*}{ Cell material } & & \multicolumn{2}{l}{ Cell efficiency (in \%) (last 10 years) } & \multirow{2}{*}{ PV Production in 2014 (GWp) } \\
\cline { 3 - 5 } & & Lab & Commercial & 16.9 \\
\multirow{2}{*}{ Crystalline silicon } & Mono & 25.6 & $12-17$ & 26.2 \\
& Multi & 20.8 & & 4.4 \\
\multirow{3}{*}{ Thin film } & Copper indium diselinide (CIGS) & 20.5 & $9-16$ & - \\
& Cadmium telluride (CdTe) & 21.0 & & - \\
\hline
\end{tabular}

Table 2. Efficiency comparison of different types of PV inverters.

\begin{tabular}{lllll}
\hline Inverter type & Power & Efficiency & Market share (in \%) & Applications \\
\hline String & up to $100 \mathrm{kWp}$ & up to $98 \%$ & 37 & Residential, small and medium commercial applications \\
Central & More than $100 \mathrm{kWp}$ & up to $98.5 \%$ & 61 & Large commercial and Utility scale \\
\hline
\end{tabular}

Ministry of New \& Renewable Energy, Government of India envisaged to set up 34 solar parks in 21 states each with a capacity of 500 to $1000 \mathrm{MW}$ thereby targeting around 20,000 MW solar generation installed capacity. These solar parks will be put in place in a span of 5 years up to 2019-2020 with a central financial assistance of Rs. 5,000 croresunder National Solar Mission. [6]

Voltage Source Converter (VSC) High Voltage Direct 
Current (HVDC) connection [7] has become a new trend for long distance offshore wind power transmission which can be adopted for Indian power sector rather than High Voltage Alternative Current (HVAC) sub-marine cable transmission system due to surplus charging current of the cables. A typical VSC HVDC transmission system is comprised of converters, transformers and phase reactors, AC filters, DC cables and breakers, and DC capacitors and filters, as illustrated in Fig. 8

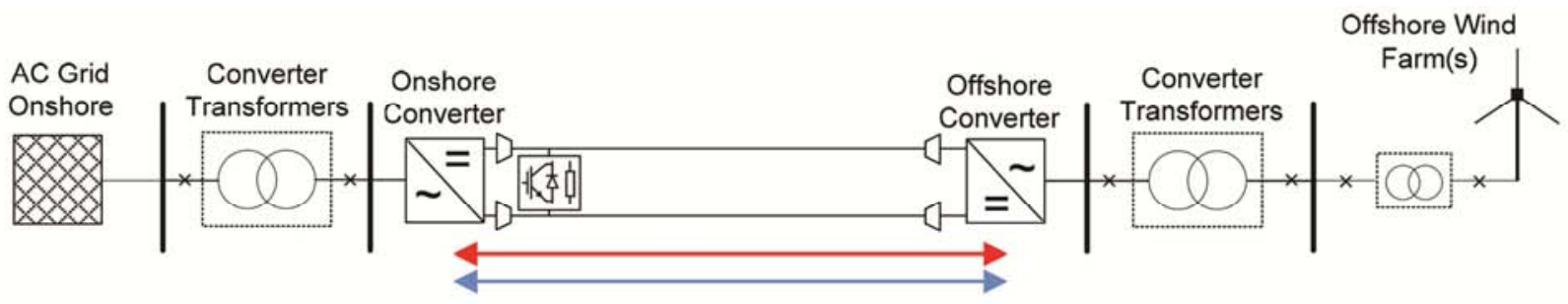

Figure 8. Grid connection of offshore wind farm through VSC HVDC transmission system.

Capabilities of VSC HVDC transmission systems and benefits for wind farms and Transmission System Operators (TSOs) are mentioned below

a) Active power control and frequency response capability

b) Reactive power control and voltage support capability

c) Fast response to disturbances

d) Decoupling AC systems

e) Black start capability

\section{Environmental Impacts and Suggestions for Renewable Energy Development}

$21^{\text {st }}$ Conference Of Parties (COP21), United Nations Framework Convention on Climate Change (UNFCCC), shapes the world's response to the threat of catastrophic climate change. Renewable energy technologies can deliver half of the emission reductions needed to keep the global temperature rise within $2^{\circ} \mathrm{C}$ by the end of the century. It is strongly believed that renewables will be part of any viable climate solution. India's Intended Nationally Determined Contributions (INDC) towards UNFCCC includes reducing emissions intensity of its GDP by $33-35 \%$ by 2030 from the 2005 level, achieving about $40 \%$ cumulative electric power installed capacity from non fossil fuel based energy sources by 2030 with the help of transfer of technology and low cost international finance, including from Green Climate Fund, creating additional carbon sink of 2.5 to 3.0 billion tones of $\mathrm{CO}_{2}$ equivalent through additional forest and tree cover by 2030. The Copenhagen Accord is a significant step forward in forging international cooperation to tackle global warming. India committed to reducing its emissions intensity by 20 to 25 percent below 2005 levels by 2020 . To meet and exceed this goal, India is increasing fuel efficiency standards by 2011; adopting building energy codes by 2012; increasing forest cover to sequester 10 percent of India's annual emissions; increasing the fraction of India's electricity derived from wind, solar, and small hydro to 20 percent by 2020 (from the current level of 8 percent). [8].

IRENA analysis observes that doubling the share of renewable energy by 2030 could deliver around half of the required emissions reductions and, coupled with energy efficiency, keep the average rise in global temperatures below $2^{\circ} \mathrm{C}$ and prevent catastrophic climate change. It is expected that, with the right policies, global annual investment in renewables can reach 900 billion USD, generate over 24 million jobs worldwide by 2030. [9].

Five clear actions suggested by IRENA to support the renewable energy transition are

a) Strengthening the policy commitment to renewable energy;

b) Mobilise investment in renewable energy;

c) Building institutional, technical and human capacity to support renewable energy deployment.

d) Harnessing the cross-cutting impact of renewables on sustainable development;

e) Enhancing regional engagement and international cooperation.

Roles of state and central government agencies in policy development, regulation, and promotion of renewable energy in India are listed in Table 3. [10]

Table 3. India's renewable energy stakeholder's roles and responsibilities.

\begin{tabular}{|c|c|c|c|}
\hline Level & $\begin{array}{l}\text { Central government } \\
\text { (Ministry of Power/ } \\
\text { Ministry of Finance) }\end{array}$ & MNRE & CERC \\
\hline Central & $\begin{array}{l}\text { Develops national } \\
\text { electricity tariff policies, } \\
\text { which also cover } \\
\text { renewable energy } \\
\text { - Provides fiscal } \\
\text { incentives for } \\
\text { promoting renewable } \\
\text { energy }\end{array}$ & $\begin{array}{l}\text { - Develops national renewable energy laws } \\
\text { - Sets technical standards for renewable energy } \\
\text { - Conducts resource assessments for renewable } \\
\text { energy; supports R\&D in renewable energy } \\
\text { technologies } \\
\text { - Promotes effective use of information technology } \\
\text { for renewable energy, manages database } \\
\text { - Reviews renewable energy programs to understand their effectiveness } \\
\text { and efficiency }\end{array}$ & $\begin{array}{l}\text { - Sets guidelines for } \\
\text { feed-in tariff design } \\
\text { for different renewable } \\
\text { energy technologies } \\
\text { - Regulates the regional } \\
\text { electricity corporation } \\
\text { mechanism } \\
\text { - Regulates interstate } \\
\text { open access, and third party sales }\end{array}$ \\
\hline
\end{tabular}




\begin{tabular}{|c|c|c|c|}
\hline Level & $\begin{array}{l}\text { Central government } \\
\text { (Ministry of Power/ } \\
\text { Ministry of Finance) }\end{array}$ & MNRE & CERC \\
\hline State & $\begin{array}{l}\text { State government } \\
\text { - Develops state- level } \\
\text { renewable energy } \\
\text { policy } \\
\text { - Provides fiscal } \\
\text { incentives for } \\
\text { promoting renewable } \\
\text { energy sources }\end{array}$ & $\begin{array}{l}\text { State nodal agency } \\
\text { - Conducts resource assessments for various } \\
\text { renewable energy sources } \\
\text { - Allocates renewable energy projects and progress monitors } \\
\text { - Provides facilitation services to project developers } \\
\text { - IREDA personnel escort project developers to } \\
\text { various government departments with the objective } \\
\text { of facilitating and streamlining clearances } \\
\text { - Facilitates clearances and land acquisition } \\
\text { - Creates awareness and educates the masses } \\
\text { about adoption of renewable energy } \\
\text { - Maintains database on renewable energy sources }\end{array}$ & $\begin{array}{l}\text { SERCs } \\
\text { - Develops feed-in tariff } \\
\text { methodologies for } \\
\text { different renewable } \\
\text { energy technologies } \\
\text { - Determines RPOs } \\
\text { and enforcement } \\
\text { mechanism } \\
\text { - Sets regulations on } \\
\text { intrastate wheeling, } \\
\text { open access, and third party } \\
\text { sale }\end{array}$ \\
\hline
\end{tabular}

NITI Aayog, a think tank, Government of India in its report onIndia'sRenewable Electricity Roadmap 2030. Toward AcceleratedRenewable Electricity Deployment identified four areas from stakeholder interviews and international experience, which are listed below as [11]:

a) A Comprehensive national policy framework for renewable energy (RE)

b) Willing and Credit-Worthy Buyers (i.e. Discoms) for $\mathrm{RE}$

c) Smoother RE project development environment

d) Updated grid planning and operation

It suggest the following key policy recommendations to ensure

1) National RE law and/or policy

2) Establish targets

3) Identify financial support required for achieving targets

4) Undertake integrated energy resources planning

5) Take a programmatic approach by having restructured and enforceable RPO and mandatory net metering (NEM)/feed-in tariff (FiT)

A. Support Mechanisms for Compliance and Timely Implementation

1) "One-Stop Shop" for standardized contracting

2) Financial support and disbursal mechanism

3) Streamlined project development

4) Low-cost financing

B. RE Grid Integration and More Efficient Grid Operation

1) Upgrade grid technology

2) Upgrade grid operation protocols with grid codes and 5-minute scheduling and dispatch

3) Expand balancing areas

4) Promote flexible demand and supply resources

\section{Conclusions}

Renewable energy increasingly play an important role in the overall energy mix of the world and will continue to contribute towards addressing the present and future power supply deficits as well as enhancing the energy access in remote areas. Accelerated development of renewable energy sources will have a vital role in the development of power infrastructure, and in the utilization of sustainable energy of the world. The renewable energy sector/industry, grid operators and utilities would need to develop new technologies and strategies to integrate them into flexible, efficient and smart grids.

\section{Acknowledgements}

The author wish to acknowledge the financial support for the project titled, "Design, development and deployment of Grid interfaced power conversion unit for solar - wind power generation system", by Central Power Research Institute, A Government of India Society, Ministry of Power, Bangalore through RSOP Project (Project Code: RSOP/2015/DG/6/15122015). The authors thank the management of Arunai Engineering College, Tiruvannamalai for providing the opportunity and facilities to do this work.

\section{References}

[1] V. Saravanan, M. Arumugam, R. Venkatesan "Progress of Solar Photovoltaic Systems in India" $32^{\text {nd }}$ European Photovoltaic Solar Energy Conference and Exhibition (EUPVSEC 2016), 2016, pp. no. 2933-2936.

[2] V. Saravanan, M. Arumugam, "Wind power developments in India: A way forward" All India Power Seminar - 2016(Present Scenario in Power Sector \& Future Challenges) on the eve of Diamond Jubilee Celebrations, NLC INDIA LIMITED (Formerly Neyveli Lignite Corporation Limited), Neyveli, Tamilnadu, India. (pg.no. 103 to 107,Renewable Energy Section)

[3] V. Saravanan, M. Arumugam, "Solar Photovoltaic Systems in India: Progress, Barriers, Challenges, Impacts, Merits, Recommendations and Vision for the Future" All India Power Seminar - 2016(Present Scenario in Power Sector \& Future Challenges) on the eve of Diamond Jubilee Celebrations, NLC INDIA LIMITED (Formerly Neyveli Lignite Corporation Limited), Neyveli, Tamilnadu, India. (pg. no. 2 to 8,88 to 102 , Renewable Energy Section).

[4] http://www.nrel.gov/cellefficiencychart.html[Accessed January 18, 2017]

[5] Photovoltaics report, Fraunhofer Institute for Solar Energy Systems, ISE, Freiburg, 17 November 2016, www.ise.fraunhofer.de

[6] V. Saravanan,M. Arumugam, S. Ganesh Babu "Development of Solar Parks in India" $26^{\text {th }}$ International Photovoltaic Science and Engineering Conference (PVSEC-26), 2016 (Poster) 
[7] Asimenia Korompili, Qiuwei Wu, Haoran Zhao. Review of VSC HVDC connection for offshore wind power integration. Renewable and Sustainable Energy Reviews 59(2016)14051414.

[8] http://www4.unfccc.int/submissions/indc/Submission\%20Pag es/submissions.aspx./India/./INDIA\%20INDC\%20TO\%20UN F...Sep 25, 2015.

[9] www.irena.org IRENA (2015), 'REthinking Energy: Renewable Energy and Climate Change'.
[10] "Sargsyan, Gevorg; Bhatia, Mikul; Banerjee, Sudeshna Ghosh; Raghunathan, Krishnan; Soni, Ruchi. 2011. Unleashing the Potential of Renewable Energy in India. World Bank Study. World Bank. (C) World Bank.

https://openknowledge.worldbank.org/handle/10986/2318 License: CC BY 3.0 IGO.

[11] http;//niti.gov.in//Report_on_India's_RE_Roadmap_2030-full report-web.pdf/ Report on India's Renewable Electricity Roadmap 2030. Toward Accelerated Renewable Electricity Deployment. NITI Aayog. 